\title{
Cerebrospinal fluid oestrone in pseudotumour cerebri
}

\author{
JAMES O DONALDSON, ${ }^{*}$ EVA HORAK $\dagger$ \\ From the Departments of Neurology and Internal Medicine, ${ }^{*}$ and of Laboratory Medicine, $\dagger$ University of \\ Connecticut School of Medicine, Farmington, Connecticut, USA
}

SUMMARY The concentration of oestrone in the cerebrospinal fluid (CSF) from obese young women with pseudotumour cerebri was much greater than predicted and found in normal subjects. Each woman with pseudotumour cerebri, and a high level of CSF oestrone and a CSF protein less than $0.2 \mathrm{~g} / 1$, had clinical improvement when treated with an 800 calorie/day diet and dexamethasone $2 \mathrm{mg} /$ day.

Increased oestrone production in adipocytes by the aromatisation of androstenedione may be the factor responsible for obesity in the pathogenesis of pseudotumour cerebri in young fat women. ${ }^{1}$ Oestrone could cause the menstrual irregularities in such women by a direct effect upon endometrium and, perhaps, by alteration of feedback regulation of gonadotrophin secretion. Discovery of large amounts of oestrone in the cerebrospinal fluid (CSF) of an obese young women with Turner's Syndrome, pseudotumour cerebri and unexpectedly low serum gonadotrophin levels prompted this study of CSF oestrogens in pseudotumour cerebri. ${ }^{2}$

\section{Methods}

Oestrogen concentrations were determined in duplicate by one of us (EH) using commercially available radioimmunoassays: Wien Laboratories, Succasunna, $\mathrm{NJ}$, for oestrone and oestriol; CIS Radiopharmaceuticals, Bedford, Mass., for oestradiol. Oestrogens were extracted from 8 to $10 \mathrm{ml}$ of serum or CSF with methylene chloride for oestrone and oestriol determinations, and diethyl ether for oestradiol assays. Oestrone and oestriol levels less than $5 \mathrm{pg} / \mathrm{ml}$ and oestradiol levels less than $8 \mathrm{pg} / \mathrm{ml}$ were less than the sensitivity of our techniques. The antibodies used in the assays were highly specific, reacting only with closely related compounds. In the oestrone assay, $1000 \mathrm{pg}$ oestradiol was equivalent to $15 \mathrm{pg}$ oestrone, and $50000 \mathrm{pg}$ oestriol did not alter the oestrone determination. Inter-

Address for reprint requests: Dr James O Donaldson, Department of Neurology, University of Connecticut Health Center, Farmington, Connecticut 06032, USA.

Received 10 February 1982

Accepted 9 April 1982 assay and intra-assay reliability was within $10 \%$ and $3 \%$ respectively.

All patients with pseudotumour cerebri had papil- $\frac{\vec{D}}{A}$ loedema and normal CT scans. The CSF used for oes- $\frac{\rho}{\Phi}$ 음

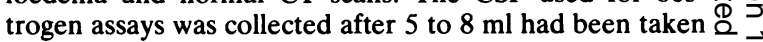
for routine diagnostic tests. Each CSF sample had a protein $\sigma$ concentration less than $0.40 \mathrm{~g} / \mathrm{l}$ with one exception. After the first lumbar puncture, pseudotumour patients numbers 1-5 were treated with an 800 calorie/day diet and dexamethasone $2 \mathrm{mg} /$ day.

\section{Results}

Oestrone, but neither oestradiol nor oestriol, was measurable in the CSF of some patients (table). Six of seven obese young women with pseudotumour cerebri had detectable CSF oestrone. Five pseudotumour patients, each of whom had CSF protein concentration less than $0 \cdot 20 \mathrm{~g} / \mathrm{l}$, had clinical improvement as manifested by loss of diplopia, restoration of colour vision, improvement in visual acuity and lessening of headache, within 3 days after the institution of an $800 \mathrm{cal} /$ day diet and oral administration of dexamethasone, $2 \mathrm{mg} /$ day. Three of these women had suppression of the CSF concentration of oestrone with little change in serum oestrone; two did not have a second lumbar puncture. Patient number 6 did not have detectable CSF oestrone while taking dexamethasone, $0.5 \mathrm{mg}$ daily, and did three weeks after dexamethasone was discontinued due to intolerance. She failed to lose weight; treatment with furosemide and acetazolamide were unsuccessful. Ten weeks after dexamethasone was stopped and one week before a lumbar-peritoneal shunt, CSF oestrone was 270 734 
Table Serum and cerebrospinal fuid (CSF) Oestrogen concentrations

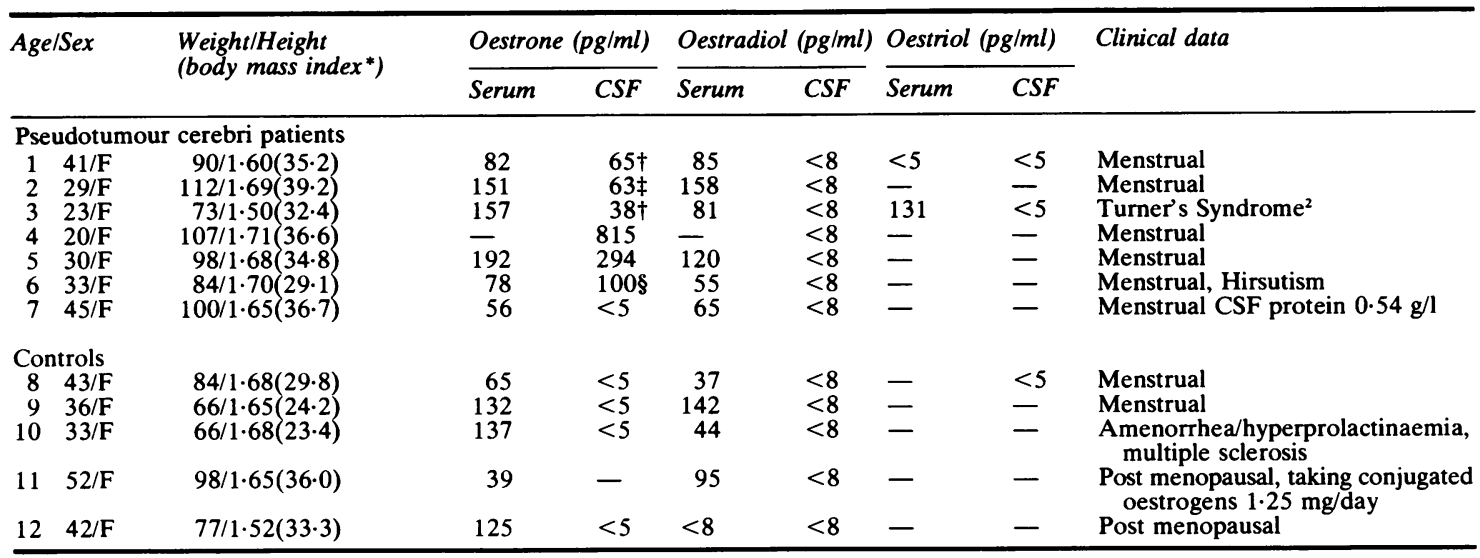

*Weight in $\mathrm{kg}$ divided by square of height in metres; $+\mathrm{CSF}$ oestrone $<5 \mathrm{pg} / \mathrm{ml}$ after 1 week of dexamethasone $2 \mathrm{mg} /$ day; $\ddagger$ CSF oestrone $25 \mathrm{pg} / \mathrm{ml}$ after 1 week and $<5 \mathrm{pg} / \mathrm{ml}$ after 3 weeks of dexamethasone $2 \mathrm{mg} /$ day; $\S C S F$ oestrone $<5 \mathrm{pg} / \mathrm{ml} 3$ weeks earlier when dexamethasone $0.5 \mathrm{mg} /$ day was discontinued.

Pseudotumour patient number 7, who did not have detectable CSF oestrone and did have an unusually high CSF protein for this syndrome, continued to have headaches and papilloedema despite a $15 \mathrm{~kg}$ weight loss and dexamethasone $8 \mathrm{mg} /$ day.

\section{Discussion}

The movement of steroid hormones from blood to CSF appears to be correlated with the concentration of plasma-protein-unbound steroid rather than with lipid solubility. ${ }^{3-7}$ Cortisol is more lipid soluble and had less plasma-protein affinity than oestradiol. In monkeys, the CSF concentration of cortisol equals the plasma free-hormone level, or about $22 \%$ of total plasma cortisol. ${ }^{6}$ In monkeys and man, the CSF concentration of oestradiol approximates the unbound plasma concentration, of 3 to $4 \%$ of total plasma oestradiol..$^{7}$ The normal CSF concentration of oestradiol is less than the sensitivity of our radioimmunoassays. The CSF concentration of oestrone was expected to be unmeasurably low by our methods because oestrone, like oestradiol, has high affinity to plasma proteins. ${ }^{8}$ Instead, large amounts of oestrone were measured in the CSF of six obese young women with both pseudotumour cerebri and CSF protein concentrations less than $0 \cdot 20 \mathrm{~g} / \mathrm{l}$.

An explanation of these preliminary observations awaits a more extensive study of CSF oestrogens and more fundamental knowledge both of steroid metabolism by the brain and of the effect of steroid hormones upon the choroid plexus and the arachnoid villus. The origin of the oestrone found in CSF must be determined. It may be produced in the hypothalamus and other brain tissues and it may be transferred to CSF from blood.
The hypothesis that oestrone stimulates the secretory cells of the choroid plexus to produce more CSF than can be absorbed at normal CSF pressures potentially links pseudotumour cerebri and oestrone. ${ }^{12}$ Women with few low-pressure absorption "channels" may be able to handle normal CSF formation rates, but be unable to absorb CSF formation at higher rates unless high CSF pressure increases bulk flow through the arachnoid villi. If oestrone does stimulate CSF production, the pseudotumour cerebri of fat young women may be treated by decreasing oestrone synthesis from androstenedione by adipocytes by means of adrenal suppression and weight reduction. Alternatively an oestrone receptor antagonist might be effective. The detection of large concentrations of oestrone in the CSF of patients with pseudotumour cerebri does not prove that oestrone is involved in the pathogenesis of pseudotumour cerebri, but it is an observation to be confirmed and explained.

\section{References}

' Donaldson JO. Pathogenesis of pseudotumor cerebri syndromes. Neurology (Ny) 1981;31:877-80.

${ }^{2}$ Donaldson JO, Binstock ML. Pseudotumor cerebri in an obese young woman with Turner's Syndrome. Neurology (Ny) 1981;31:758-60.

${ }^{3}$ Marynick SP, Wood JH, Loriaux DL. Cerebrospinal fluid steroid hormones. In: Wood JH, ed. Neurobiology of cerebrospinal fuid. New York: Plenum Press, 1980:605-11.

${ }^{4}$ David GFX, Kumar TCA. Transfer of steroidal hormones from blood to the cerebrospinal fluid in the rhesus monkey. Neuroendocrinology 1974;14:114 20. 
${ }^{5}$ Marynick SP, Havens WW, Ebert MH, Loriaux DL. Studies on the transfer of steroid hormones across the blood cerebrospinal fluid barrier in the rhesus monkey. Endocrinology 1976;99:400-5.

- Marynick SP, Smith GB, Ebert MH, Loriaux DL. Studies on the transfer of steroid hormones across the blood cerebrospinal fluid barrier in the rhesus monkey. II.
Endocrinology 1977;101:562-7.

${ }^{7}$ Bakstrom T, Carstensen H, Sodergard R. Concentration of estradiol, testosterone and progesterone in cerebrospinal fluid compared to plasma unbound and total concentrations. J Steroid Biochem 1976;7:469-72.

${ }^{8}$ Struck $H$. Über die bindung von Östron, $17 \beta$-Östradiol und Östriol an Proteine in vitro. Hoppe-Seyler's $Z$ Physiol Chem 1963;333:89-98. 